\title{
Ventilation of the deep ocean 2.2 billion years ago: Evidence from the Birimian Greenstone Belt, Ghana
}

\author{
KOSEI E YAMAGUCHI ${ }^{1}$, MINORU IKEHARA ${ }^{2}$, SHOICHI \\ KIYOKAWA ${ }^{3}$, TAKASHI ITO ${ }^{4}$ AND TETSUJI ONOUE ${ }^{3}$ \\ ${ }^{1}$ Toho University \\ ${ }^{2}$ Kochi University \\ ${ }^{3}$ Kyushu University \\ ${ }^{4}$ Ibaraki University \\ Presenting Author: kosei@chem.sci.toho-u.ac.jp
}

The Paleoproterozoic Era has been characterized by an inferred rapid rise of atmospheric oxygen at around 2.4-2.2 Ga. Oxygenation of the surface environment of the Earth was most likely to have been heterogeneous; molecular oxygen produced by oxygenic photosynthesis first oxygenated the surface ocean after oxidizing dissolved reduced species such as Fe and $\mathrm{S}$, then excess oxygen was liberated into the atmosphere and transported to deep ocean by ocean circulation. Although the timing of GOE has long been debated, such stepwise oxygenation itself appears widely accepted.

Geological and geochemical evidence to support such Paleoproterozoic GOE is largely based on characteristics of sedimentary rocks that formed in rather shallower environments, such as shallow marine or continental settings, namely carbonates, shallow-facies shales, and paleosols. Since there is a general lack of least-metamorphosed deep-facies siliceous sedimentary rocks that were deposited right after the inferred GOE, studies that geochemically constrain the degree of oxygenation of the deep ocean are hampered.

We conducted continental drilling to obtain 2.2 Ga leastmetamorphosed deep-facies sedimentary rocks from the Birimian Greenstone Belt, Ghana. The 196m-long core at low-grade metamorphism (upto greenschist facies) comprises basaltic volcanic rocks and fine-grained sedimentary rocks. Here we report results of major element analysis by XRF, trace and rare earth element analysis by ICP-MS, Fe-speciation $\left(\mathrm{Fe}_{\mathrm{py}}, \mathrm{Fe}_{\text {carb }}\right.$, $\mathrm{Fe}_{\mathrm{ox}}, \mathrm{Fe}_{\mathrm{mag}}$, and $\left.\mathrm{Fe}_{\mathrm{HCl}}\right)$ analysis, $\mathrm{S}$-speciation analysis, $\mathrm{C}_{\text {org }}$ and $\mathrm{C}_{\text {carb }}$ analysis, and $\mathrm{C}_{\text {org }}$ and $\mathrm{S}_{\mathrm{py}}$ isotope analysis for 25 samples selected from $20 \mathrm{~m}$-long sedimentary unit of the core.

The data set consistently suggests that redox state in the 2.2 $\mathrm{Ga}$ deep ocean was essentially oxic, with temporal anoxic/euxinic transitions. Enhanced continental weathering under an oxic atmosphere would have increased nutrient input into the ocean, primary productivity, consumption of dissolved $\mathrm{O}_{2}$, and sporadic emergence of euxinic conditions.

Redox state of the deep ocean right after the inferred GOE would place important constraints on the co-evolution of the atmosphere, ocean, and biosphere. 